\title{
Pelatihan Pengenalan Sistem Informasi Manajemen Dan Sukses Menjadi Content Creator
}

\author{
Slamet Heri Winarno ${ }^{1}$, Wiwin Wianti ${ }^{2}$, Dahlia Sarkawi ${ }^{3}$ \\ ${ }^{1,2,3}$ Universitas Bina Sarana Informatika \\ Jalan Kramat Raya No.98 Kwitang Senen Jakarta, Indonesia \\ e-mail: ${ }^{1}$ slamet.smh@bsi.ac.id, ${ }^{2}$ wiwin.win@bsi.ac.id, ${ }^{3}$ dahlia.dls@bsi.ac.id
}

\begin{abstract}
Abstrak
Kegiatan pengabdian kepada masyarakat $(\mathrm{PkM})$ dosen Program Studi Administrasi Perkantoran Fakultas Ekonomi dan Bisnis Universitas BSI difokuskan pada pelatihan pengenalan sistem informasi manajemen dan sukses menjadi content creator bagi pengurus dan anggota Karang Taruna Rt 016 Kapuk Cengkareng yang merupakan organisasi kepemudaan yang memiliki visi mengembangkan setiap potensi personil anggotanya sekaligus sebagai mitra PkM. Permasalahan yang terdapat pada mitra diantaranya: terbatasnya pengetahuan mengenai penerapan Sistem Informasi Manajemen sebagai alat untuk pengembangan organisasi, belum maksimalnya pemanfaatan sarana digital seperti internet, handphone dalam menghasilkan konten kreatif, ide-ide atau gagasan yang inovatif masih belum tergali dengan baik. Solusi yang ditawarkan meliputi memberian pengetahuan secara komprehensif tentang konsep dasar sistem informasi manajemen, emberikan kiat sukses menjadi seorang content creator merubah midset peserta untuk lebih berpikir kreatif. Pelaksanaan PkM ini dilakukan secara daring (online) menggunakan media zoom meeting. Hasil dari kegiatan ini berupa publikasi pada media dan jurnal serta peningkatan pengetahuan dan keterampilan mitra.
\end{abstract}

Kata Kunci: Sistem Informasi Manajemen, Content Creator, Karang Taruna

\begin{abstract}
Community service activities (PkM) lecturers of the Office Administration Study Program, Faculty of Economics and Business, BSI University are focused on training on the introduction of management information systems and being successful as content creators for administrators and members of Karang Taruna Rt 016 Kapuk Cengkareng which is a youth organization that has a vision of developing every potential its member personnel as well as PkM partners. Problems encountered by partners include: limited knowledge about the application of Management Information Systems as a tool for organizational development, not yet maximal use of digital facilities such as the internet, mobile phones in producing creative content, innovative ideas or ideas that have not been explored properly. The solutions offered include providing comprehensive knowledge about the basic concepts of management information systems, providing tips for success in becoming a content creator, changing the participant's midset to think more creatively. The implementation of this PkM is carried out online using the zoom meeting media. The results of this activity are publications in the media and journals as well as increased knowledge and skills of partners.
\end{abstract}

Keywords: Management Information System, Content Creator, Youth Organization 


\section{Pendahuluan}

Pelaksanaan pengabdian kepada masyarakat didasarkan pada Undang-Undang Nomor 20 Tahun 2003 tentang Sistem Pendidikan Nasional dalam pasal20 ayat (2) Perguruan Tinggi berkewajiban menyelenggarakan pendidikan,penelitian dan pengabdian kepada masyarakat serta Pasal 24 ayat (2) perguruan tinggi memiliki otonomi untuk mengelola sendiri lembaganya sebagai pusat penyelenggaraan pendidikan tinggi, penelitian ilmiah, dan pengabdian kepada masyarakat; serta Undang-undang Nomor 14 Tahun 2005 tentang Guru dan Dosen dalam Pasal 51 ayat (1) huruf d bahwa dalam melaksanakan tugas keprofesionalan, dosen berhak memperoleh kesempatan untuk meningkatkankompetensi, akses sumber belajar, informasi, sarana dan prasarana pembelajaran, serta penelitian dan pengabdian kepada masyarakat.

Menghadapi era digitalisasi saat ini diperlukan adanya peningkatan kualitas sumber daya manusia terutama dalam penguasaan IT melalui pelatihan-pelatihan. Pada kegiatan PkM kali ini pelatihan yang dilakukan yaitu pelatihan pengenalan sistem informasi manajemen (SIM) dan sukses menjadi content creator, sasaran utama pelatihan ini yaitu pengurus dan anggota Karang Taruna Rt 016 Kapuk Cengkareng.

Dewasa ini seluruh aktivitas baik organisasi dan bisnis telah menggunakan sistem informasi manajemen dan terintegrasi antara satu kegiatan dengan kegiatan lainnya secara digital. Sistem informasi manajemen (SIM) adalah sistem perencanaan bagian dari pengendalian internal dalam bisnis yang terdiri atas pemanfaatan dokumen, manusia, teknologi, serta prosedur dalam akuntansi manajemen (Sutanta, 2016). Ditinjau dari segi tujuan dan manfaatnya penerapan SIM dalam berbagai aktivitas akan membawa dampak perubahan terutama pada produktivitas kerja (Rahmani, 2019). Telah banyak bidang-bidang bisnis dan organisasi yang menerapkan SIM dalam berbagai aktivitas mereka (Ladjamudin, 2012).

Selain mengenal tentang dunia IT, (Chusna, 2018) mengatakan para remaja sekarang juga harus mampu menjadi insan-insan yang inovatif dan kaya akan gagasan atau ide, salah satunya menjadi content creator di dunia maya (youtube). Selain dapat menuangkan ide/gagasan, sisi lain dari kelebihan menjadi content creator adalah dapat menghasilkan pendapatan bagi diri masing-masing yang tentunya akan menjadi sesuatu yang besar bagi remaja saat ini (Azizah, 2020).

Hampir diseluruh aktivitas dewasa ini telah terkoneksi dalam satu jaringan melalui kecanggihan IT (Ladjamudin, 2012). (Sutanta, 2016) mengungkapkan tidak hanya pada urusan bisni saja namun juga pada pengelolaan sebuah organisasi, melalui sistem informasi manajemen (SIM). (Gupron, 2019) mengatakan bahwa keberadaan SIM ini telah membantu organisasi dalam meningkatkan kinerja (performance). SIM dirancang untuk mengubah data dalam bentuk informasi digital. Jadi data tersebut dikumpulkan dan digunakan untuk mendukung proses pengambilan keputusan dalam sebuah organisasi, apapun jenis organisasinya (Hendrik et al., 2016). Penggunaan SIM ini tentunya akan memudahkan berbagai macam permasalahan-permasalahan yang terjadi di dalam organisasi dapat cepat diatasi dan diambil keputusannya (Rahmani, 2019). Kesemuanya menjadi hal yang patut diajarkan pada generasi muda khususnya yang ada dalam organisasi sehingga mereka paham tentang bagaimana mengelola sebuah organisasi (Rosidah, 2019).

Di sisi lain, kemajuan teknologi informasi saat ini juga banyak dimanfaatkan oleh sebagian orang untuk dapat berkreasi menciptakan ide-ide inovatif dengan menjadi content creator atau lebih tenarnya menjadi seorang youtuber (Chusna, 2018).

Konten kreatif adalah informasi yang berisi hal-hal yang diciptakan dengan menggunakan berbagai macam pendekatan baik yang belum pernah ada sebelumnya atau hal lama namun dikemas lagi mengikuti perkembangan sekarang (Azizah, 2020). Sedangkan content creator 
adalah sebuah profesi yang membuat suatu konten, baik berupa tulisan, gambar, video, suara, ataupun gabungan dari dua atau lebih materi. Konten-konten tersebut dibuat untuk media, terutama media digital seperti Youtube (Putra, 2019). Semakin maraknya youtuber-youtuber muda yang berhasil menjadi content creator dapat dianggap sebagi sebuh peluangbagi generasi milenial saat ini yang sangat dekat dengan sosial media (Chusna, 2018). Salah satu upayanya dapat dilakukan dengan memberikan pelatihan atau penyuluhan tentang mengenal SIM dan menjadi content creator terutama melalui media Youtube, seoerti yang dilakukan oleh dosen FEB UBSI. Pelaksanaan pelatihan ini dilaksanakan di Karang Taruna RT 016/016 Kapuk, Cengkareng yang memiliki keanggotaan lebih kurang 25 orang yang merupakan kaum generasi muda/milenial. Karang Taruna RT06 dibentuk dengan memiliki misi yaitu mengembangkan potensi yang dimiliki tiap-tiap anggotanya.

Sebagai organisasi sosial kepemudaan Karang Taruna merupakan wadah pembinaan dan pengembangan serta pemberdayaan dalam upaya mengembangkan kegiatan sosial lingkungan sekitar dengan pendayagunaan semua potensi yang tersedia dilingkungan seperti sumber daya manusia.

Dalam rangka mewujudkan hal tersebut maka harus diadakan pelatihan atau penyuluhan bagi pengurus dan anggta di Karang Taruna RT016 Kapuk Cengkareng ini agar mampu untuk melihat peluang dan prospek dari pengetahuan tentang sistem informasi manajemen dan menjadi content creator yang sukses.

Pelaksanaan kegiatan pelatihan akan dilakukan secara daring (online), hal ini mempertimbangkan situasi dan kondisi yang tengah terjadi yaitu pandemik Covid-19 juga penerapan kebijakan Pemberlakuan Pembatasan Kegiatan Masyarakat (PPKM) yang tidak memungkinkan berkumpulnya orang, juga sebagai langkah dalam menerapkan protokol kesehatan seperti yang di keluarkan oleh pemerintah.

Pelaksanaan pengabdian masyarakat dosen Administrasi Perkantoran FEB Universitas Bina Sarana Informatika dengan topik pelatihan optimalisasi sosial media sebagai digital marketing dengan memilih Karang Taruna RT016. Hasil pengamatan yang dilakukan oleh tim abdimas menunjukkan terjadi beberapa permasalahan yang melatarbelakangi dilakukannya pelatihan, yaitu:

1. Terbatasnya pengetahuan mengenai penerapan Sistem Informasi Manajemen sebagai alat untuk pengembangan organisasi.

2. Belum maksimalnya pemanfaatan sarana digital seperti internet, handphone dalam menghasilkan konten kreatif

3. Ide-ide atau gagasan yang inovatif masih belum tergali dengan baik

\section{Metode}

Metode pelaksanaan yang digunakan dalam menyelesaikan permasalahan pada Karang Taruna RT016 Kapuk Cengkareng, yaitu:

1. Tahap persiapan

Tahap ini dilakukan untuk mengetahui permasalahan yang dihadapi oleh Karang Taruna RT 016 Kapuk Cengkareng dan mengajukan perijinan untuk melakukan kegiatan pelatihan pada pengurus karang taruna dan instansi terkait. Selanjutnya melakukan persiapan untuk pelatihan dengan membuat materi pelatihan dan kuesioner untuk mengetahui respon dari pesera pelatihan, serta fasilitas zoom meeting.

2. Tahap pelaksanaan
a. Pelatihan Pengenalan SIM

Penjabaran tetang konsep SIM, tujuan, manfaat, dan pengaruhnya terhadap organisasi.

b. Pelatihan Suskses menjadi content creator. 
Pada bagian ini para peserta akan di jelaskan tentang kiat-kiat menjadi content creator yang sukses dan mampu menghasilkan keuntungan.

3. Tahap monitoring dan evaluasi.

Pada tahap ini dilakukan dengan memberikan kuesioner yang harus diisi oleh peserta untuk mengetahui respon peserta pelatihan terhadap materi yang disampaikan.

\section{Hasil dan Pembahasan}

Karang Taruna sebagai salah satu organisasi kepemudaan merupakan wadah pembinaan dan pemberdayaan sumber daya manusis khususnya bagi remaja-remaja dan kaum muda. Peningkatan potensi dan kualitas diri tercermin dari setiap kegiatan yang dilakukan didalamnya. Demikian halnya Karang Taruna RT. 016/016 kelurahan Kapuk, Cengkareng, yang didirikan sebagai wadah perwujudan pengembangan bakat dan minat dikalangan remaja. Selain itu, kegiatan-kegiatan yang dilakukan mengarah pada kepedulian kepada masyarakat dan lingkungan sekitar wilayah Kapuk. Namun disisi lain terdapat pula kekurangankekurangan pada Karang Taruna RT 016 ini, salah satunya dalam penguasaan teknologi informasi.

Diperlukan upaya yang optimal guna menjebatani masalah ini, salah satunya dengan memberikan pelatihan bagaimana mengenal IT lebih dalam, agar remaja dan kaum muda di Karang Taruna RT 016 ini paham dan menguasai IT. Salah satu materi yang diberikan pada pelatihan ini yaitu pengenalan terhadap sistem informasi manajemen (SIM) dan mengoptimalkan kemampuan diri menjadi seorang content creator atau youtuber.

Kanal Youtube merupakan sebuah representasi dari berbagai macam ide-ide atau gagasan kreatif yang tertuang dalam sebuah tayangan. Untuk dapat membuat konten-konten yang menarik tentulah diperlukan pengetahuan dalam membuatnya. Hal ini lah yang mendorong dosen FEB Universitas Bina Sarana Informatika menjadikan Karang Taruna RT 016 Kapuk menjadi objek pelatihan sebagai bagian dari kegiatan pengabdian masyarakat $(\mathrm{PkM})$.

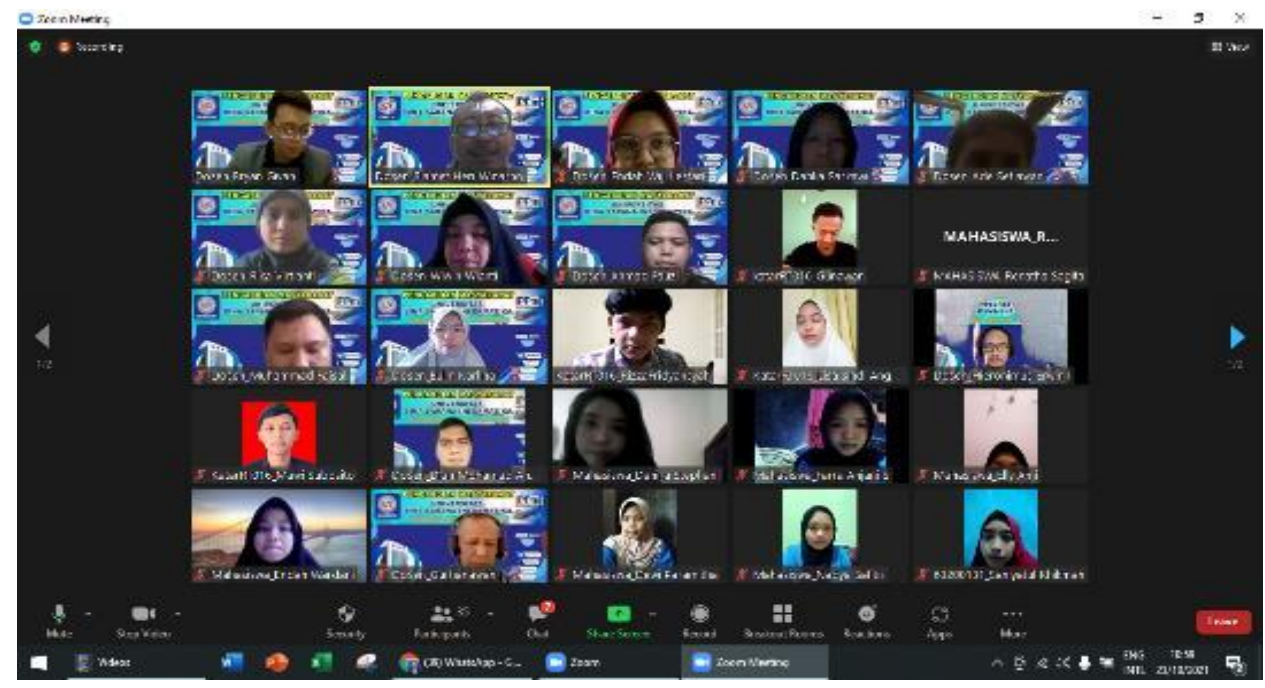

Gambar 1. Peserta PkM

Dipilihnya pelatihan pengenalan SIM dan sukses menjadi seorang content creator atau youtuber ini karena selain keterbatasan akan pengetahuan IT, juga disebabkan oleh:

1. Minimnya pengetahuan remaja Karang Taruna RT 016 akan sistem informasi manajemen sebagai alat untuk pengembangan organisasi.

2. Belum maksimalnya pemanfaatan kanal Youtube guna menghasilkan konten kreatif 
3. Ide-ide atau gagasan yang inovatif masih belum tergali dengan baik.

Pelatihan yang dilakukan secara daring tersebut selainkan melibatkan dosen FEB UBSI, Karang Taruna RT 016 sebagai mitra juga diikuti oleh mahasiswa UBSI, sebagai wujud sinergi antara dosen dan mahasiswa dalam kegiatan PkM.
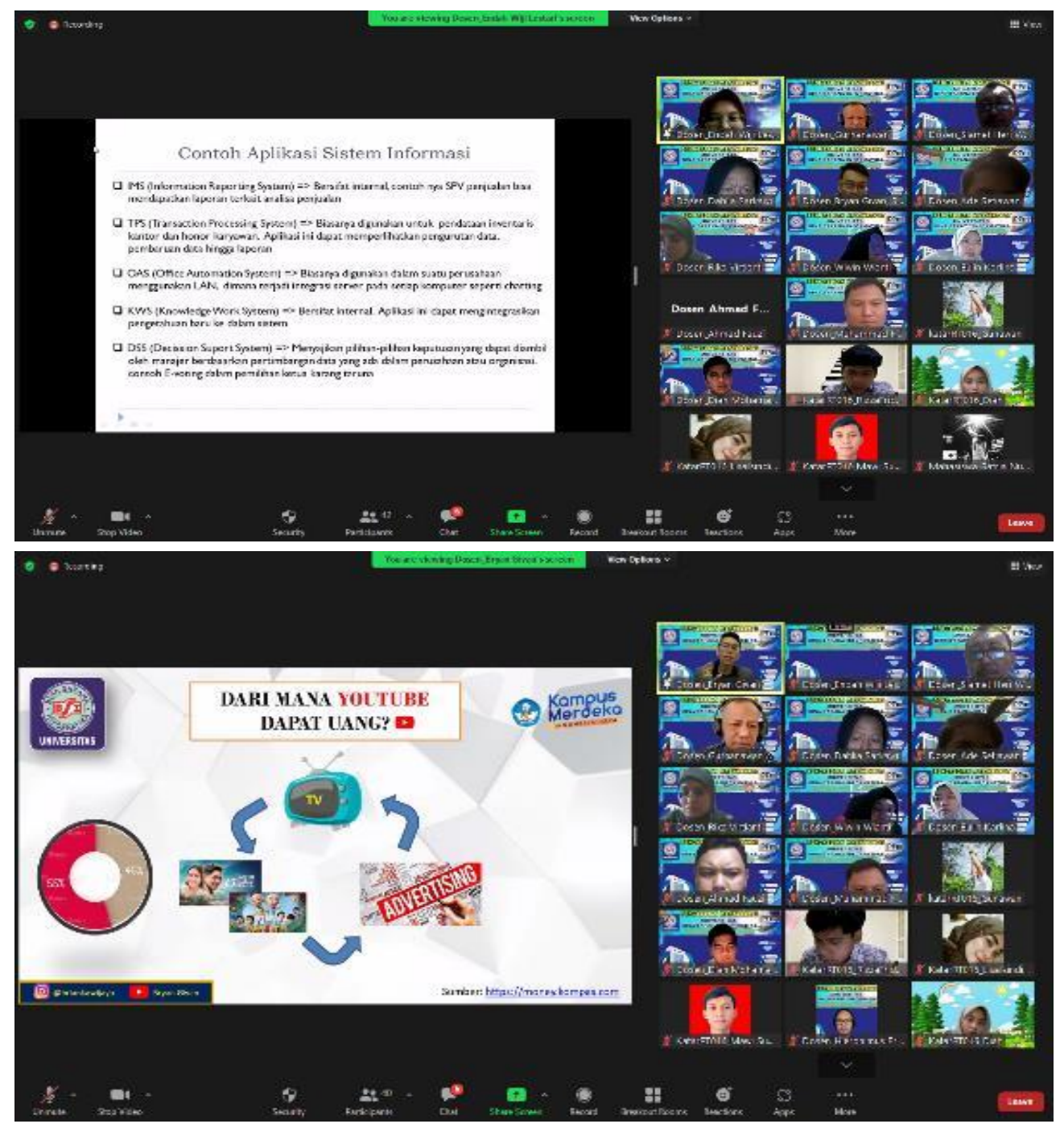

Gambar 2. Penyampaian materi PkM

Guna menilai sejauhmana pelatihan memberikan dampak pada peserta, maka dilakukan pretest dengan memberikan beberapa buah pertanyaan awal seputar tentang sistem informasi manajemen (SIM) berupa: pengertian SIM, konsep dasar SIM, bentuk-bentuk SIM, kegunaan SIM dan implementasi SIM. Hasil pengukuran menunjukkan mayoritas peserta pelatihan tidak memahami SIM dengan tujuan mengetahui pemahaman peserta terhadap SIM. Hal ini ditunjukkan lebih dari $90 \%$ pesarta memberikan jawaban tidak memahami secara mendalam tentang SIM

Melalui narasumber PkM, selanjutnya peserta diberikan materi yang berisi tentang konsep dasar SIM, mulai dari pengertian hingga implementasi SIM dalam organisasi. Guna mendapatkan gambaran tentang dampak dari pelatihan ini terhadap peningkatan pengetahuan peserta maka dilakukan posttest, untuk mengukur hasil dari pelatihan yang diberikan. Hasil 
pengukuran menunjukkan peningkatan pemahaman terhadap SIM yang signifikan. Setelah dilakukan pelatihan, pemahaman serta peningkatan pengetahuan dan keterampilan para peserta meningkat secara signifikan.

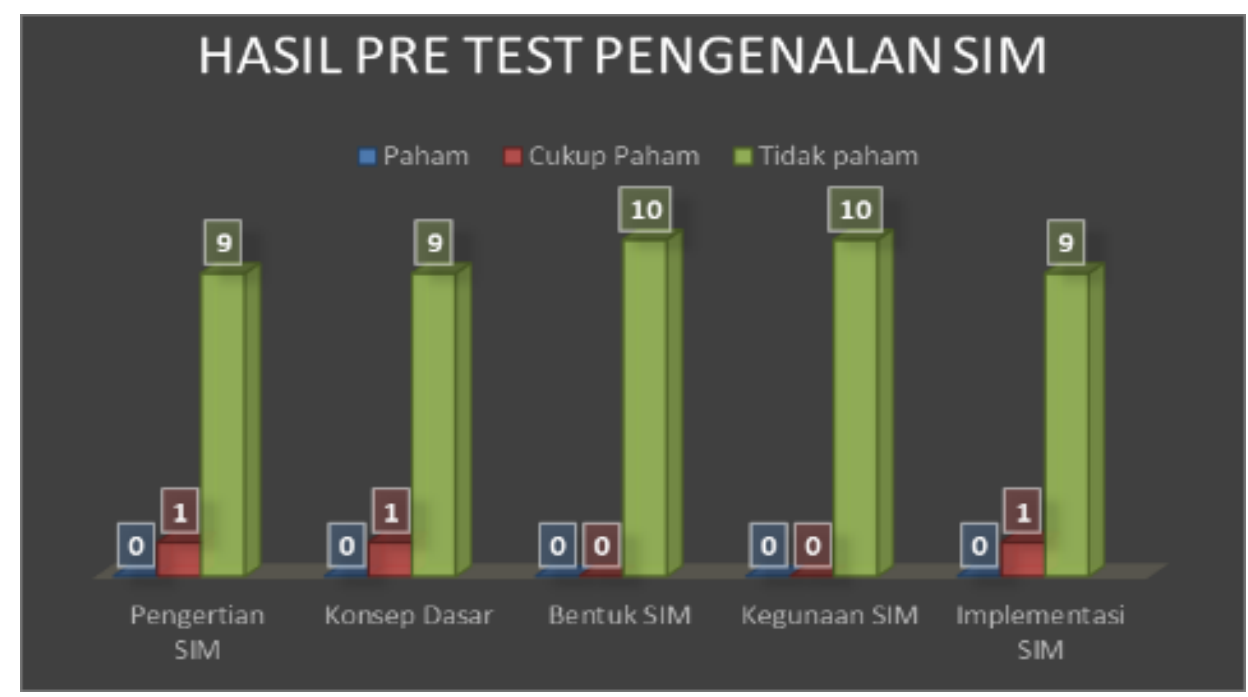

Sumber: Hasil Pengukuran (2021)

Gambar 3. Hasil Pre Test Pengenalan SIM

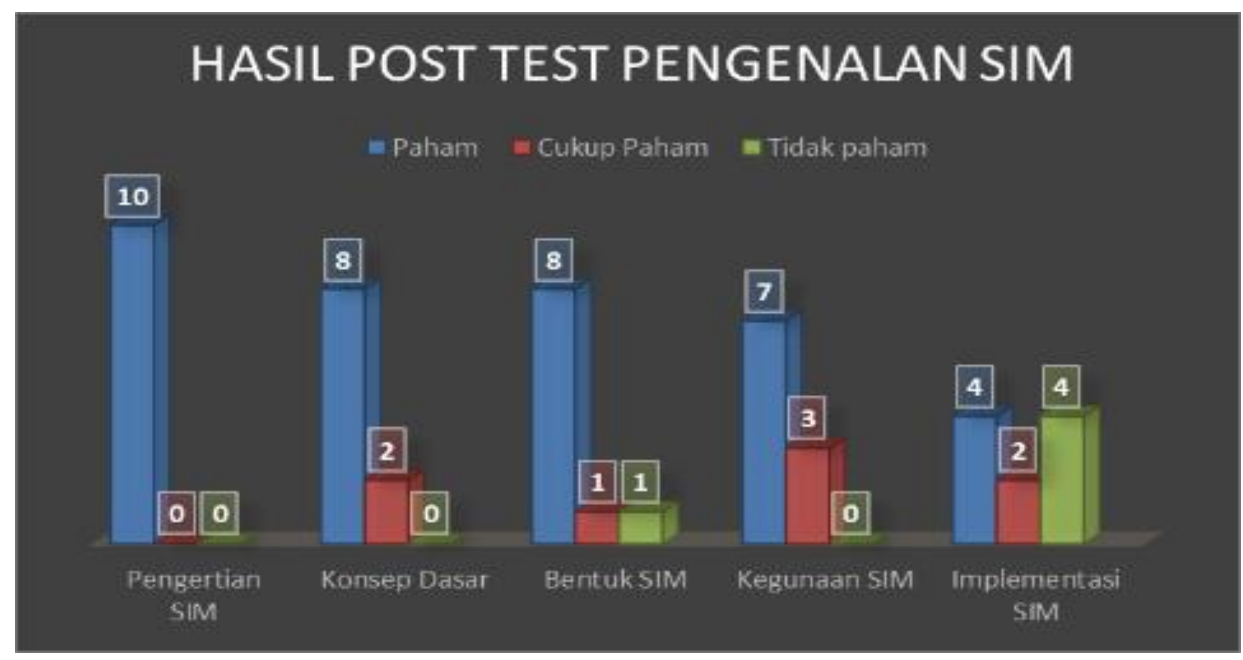

Sumber: Hasil Pengukuran (2021)

Gambar 4. Hasil Post Test Pengenalan SIM

Setelah dilakukan pelatihan seluruh pesarta memahami pengertian dari SIM, 80\% peserta juga menjadi paham akan konsep dasar dan bentuk SIM, sementara 20\% lainnya cukup paham. Demikian juga dengan kegunaan dan implementasi SIM rata 55\% peserta telah memahaminya, walaupun ada beberapa yang masih belum memahaminya. Hasil pelatihan pengenalan konsep SIM ditunjukkan pada kemampuan para pengurus dan anggota Karang Taruna 016 Kapuk dalam menerapkannya pada kegiatan-kegiatan yang merekan rencanakan, sehingga lebih terarah dan tertata dengan baik 
Sama halnya dengan pelatihan sebelumnya, pelatihan selanjutnya lebih dititikberatkan pada mengoptimalkan penggunaan media Youtube sebagai media untuk menjadi content creator. Awal pelatihan peserta melakukan pretest guna mengetahui sejauhmana pemahaman tentang content creator di Youtube.

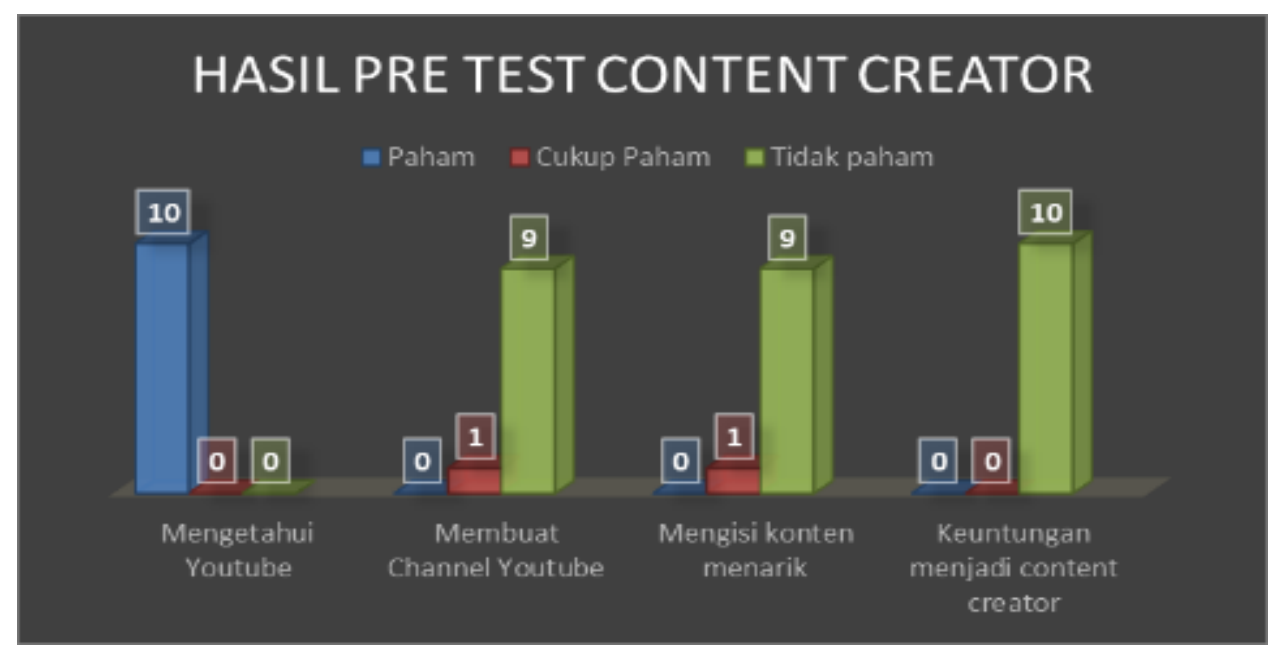

Sumber: Hasil Pengukuran (2021)

Gambar 5. Hasil Pre Test Content Creator

Hasil pengukuran menunjukkan selurih peserta tahu akan Yoube sebagai bagian dari media dunia maya. Namun pengetahuan lebih mendalam tentang menjadi content creator di Youtube mayoritas peserta tidak memahaminya, baik cara membuat channel, mengisi konten dan keuntungan jika menjadi content creator.

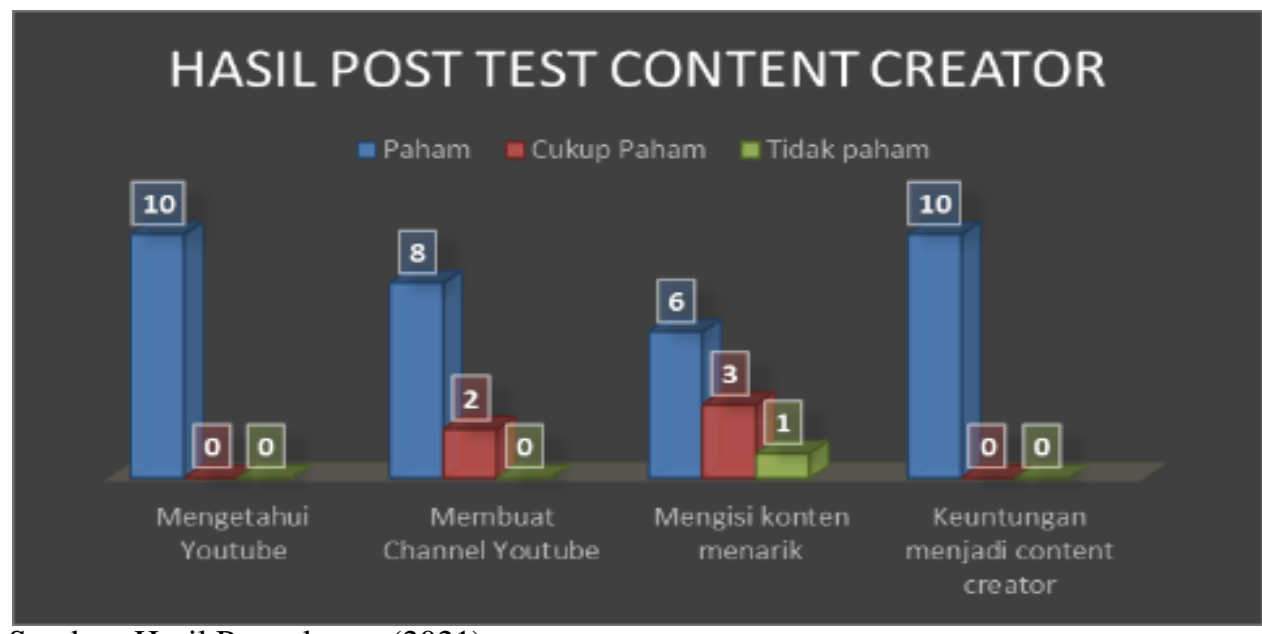

Sumber: Hasil Pengukuran (2021)

Gambar 6. Hasil Post Test Content Creator

Seluruh peserta kini paham akan Youtube dan keuntungan yang diberikan jika menjadi content creator. Namun dari aspek pemanfaatan channel Youtube menyangkut cara pembuatan dan pengisian konten menarik, tidak semua peserta memahaminya, hal ini dikarenakan adanya perbedaan pada minat, bakat serta learning fast yang ada dalam diri peserta.

Agar manfaat dari pelatihan dapat dirasakan secara nyata, dilakukan praktek langsung cara membuat konten kreatif pada kanal Youtube. Peserta terlebih dahulu diminta untuk membuat 
sebuah channel yang nantinya digunakan untuk memasukkan konten-konten kreatif. Hasil nyata dari bertambahnya pengetahuan para peserta terlihat dari hasil karya berupa tampilan channel Karang Taruna Rt 016 Kapuk di kanal Youtube yang berisi konten tentang launching Karang Taruna 016 Kapuk.

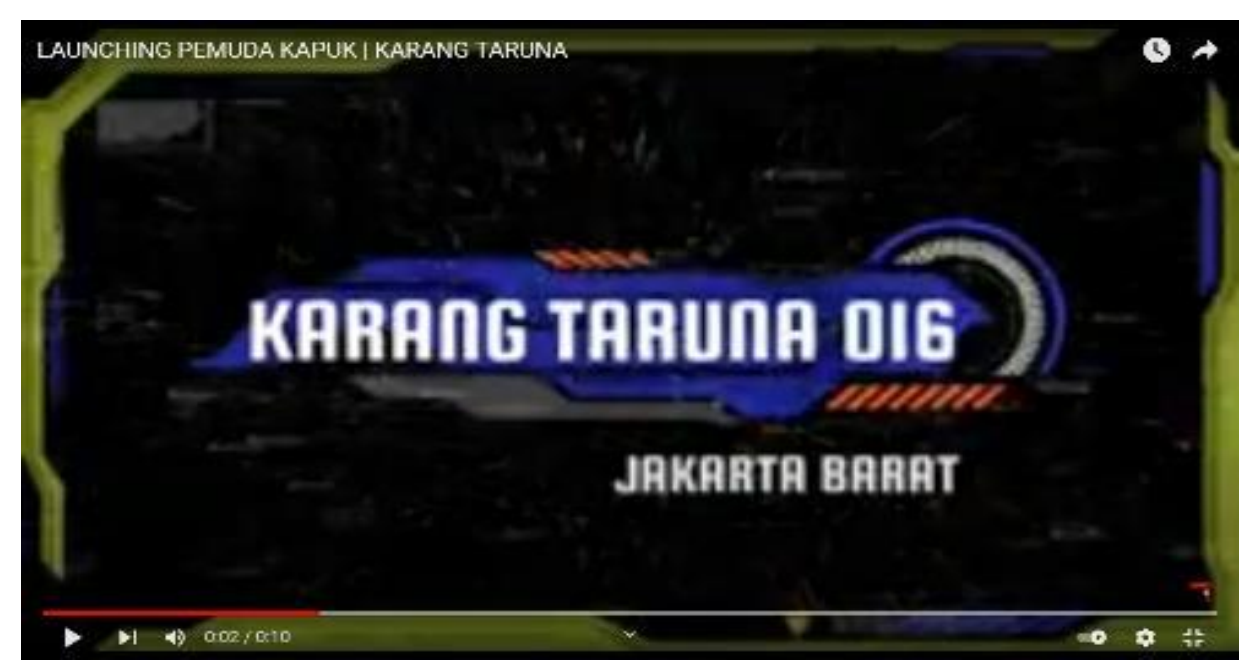

Gambar 12. Hasil Pelatihan Pembuatan Channel Youtube

Pelatihan dilakukan secara umum telah berdampak secara signifikan terhadap berbagai perubahan-peribahan baik yang bersifat materiil dan immaterial, yaitu:

1. Aspek Sumber Daya Manusia

Keinginan dari anggota dan pengurus Karang Taruna RT 016 Kapuk Cengkareng untuk dapat paham akan SIM dan menjadi content creator sangat besar, sehingga pelatihan ini telah mampu menciptakan pengetahuan dan keterampilan mengaplikasikan SIM serta belajar menjadi content creator pada Youtube dapat tercapai.

2. Aspek Manajemen Organisasi

Sebagai organisasi kepemudaan, Karang Taruna RT 016 Kapuk Cengkareng memiliki kegiatan-kegiatan yang produktif dan sangat bermanfaat bagi masyarakat sekitar, dan melalui pelatihan ini kegiatan-kegiatan tersebut dapat dikelola menggunakan SIM dan juga dapat dijadikan sebagai konten dalam channel Youtube mereka.

3. Aspek Pemanfaatan Teknologi

Secara pengetahuan pengurus dan anggota Karang Taruna RT016 Kapuk Cengkareng terbukti mampu dalam memahami pentingnya penguasaan IT, terlihat dari kemampuan mengikuti seluruh pelatihan dengan baik. Sehingga dengan pelatihan menambah kemampuan mereka dalam implementasi SIM dan menjadi content creator yang handal.

Secara umum kegiatan Pengabdian Masyarakat (PkM) ini telah memberi. dampak yang sangat positif dirasakan oleh mitra yaitu Karang Taruna RT 016 Kapuk, antara lain:

1. Meningkatnya kemampuan serta keterampilan mitra melalui pelatihan pengenalan SIM dan sukses menjadi content creator.

2. Pihak Mitra mampu menciptakan sebuah hasil berupa channel Youtube yang akan bermanfaat sebagai media dalam mensosialisasikan kegiatan-kegiatan Karang Taruna. 


\section{Kesimpulan}

Pelatihan pengenalan SIM dan sukses menjadi content creator pada anggota dan pengurus serta remaja Karang Taruna Rt 016 Kapuk Cengkareng terbukti telah mampu meningkatkan kemampuan, pengetahuan serta keterampilan tentang membangun sistem yang terintegrasi di organisasi Karang Taruna RT 016 Kapuk menjadi lebih efektif dan efisien dan juga memahami bagaimana memanfaatkan media Youtube dengan konten-konten kreatifnya. Pelatihan ini juga telah menghasilkan individu-individu yang lebih kreatif dan inovatif dalam menghasilkan konten-konten yang bagus di channel Youtube masing-masing. Sebagai tindak lanjut dari kegiatan pengabdian masyarakat $(\mathrm{PkM})$ ini adalah adanya keberlanjutan dan pendampingan bagi peserta pelatihan agar lebih handal lagi menjadi seorang youtuber atau content creator.

\section{Daftar Pustaka}

Azizah, H. (2020). Konten Kreatif Youtube Sebagai Sumberpenghasilan Ditinjau Dari Etika Bisnis Islam. Institut Agama Islam Negeri (IAIN) Metro.

Chusna, N. T. (2018). Youtubers and New Strategy of Advertising (Discourse Analysis of YouTubers as Stealth Marketing). International Journal of Progressive Sciences and ..., 1, 81-87. http://ijpsat.es/index.php/ijpsat/article/view/335

Gupron. (2019). Meningkatkan Kinerja Karyawan Melalui Sistim Informasi Manajemen dan Komunikasi (Studi pada Biro Pengelolaan Barang Milik Daerah Setda Provinsi Jambi). Jurnal Manajemen Dan Sains, 42-81. http://jmas.unbari.ac.id/index.php/jmas/article/view/73

Hendrik, J., Barusman, A. R. P., \& Habbiburahman. (2016). Pengaruh Sistem Informasi Manajemen Terhadap Kinerja Pegawai Pada Sekretariat Daerah Kabupaten Tanggamus. Jurnal Visionist, 5(1), 34-41.

Ladjamudin, A.-B. Bin. (2012). Analisis dan Desain Sistem Informasi. Yogyakarta: Graha Ilmu.

Putra, G. L. A. K. (2019). Pemanfaatan Animasi Promosi Dalam Media Youtube. Prosiding Seminar Nasional Desain Dan Arsitektur(SENADA), 2, 259-265.

Rahmani, H. F. (2019). Pengaruh Penerapan Sistem Informasi Manajemen ( SIM ) Terhadap Kinerja Karyawan. Jurnal of Economic and Entrepreneurship (Econeur), 2.

Rosidah, S. (2019). Tinjauan Hukum Islam dalam Akad Penghasilan dalam System Monetasi Youtube [UIN Raden Intan http://repository.radenintan.ac.id/7130/1/SKRIPSI.pdf

Sutanta, E. (2016). Sistem Informasi Manajemen (Edisi 3). Yogyakarta: Penerbit Andi. 